\title{
The politics of evaporation and the making of atmospheric territory in Australia's Murray-Darling Basin
}

\section{Sue Jackson and Lesley Head}

\begin{abstract}
Scholarship on the hydrosocial cycle has tended to overlook the atmospheric phase of the cycle. This paper identifies and conceptualises a politics of evaporation in Australia's Murray-Darling Basin. Evaporation is not a neutral hydrological concept to be understood, measured or acted on without an appreciation of the networks in which it originates, the geo-political circumstances that continue to shape its circulation, and its socio-spatial effects. The politics of evaporation is conceptualised here as a process of hydrosocial territorialisation in which atmospheric water came to be known as a force acting within a balanced hydrologic cycle, and 'atmospheric territory' was created. The scientific origins of evaporation show (i) how modernist hydrologic technologies and conventions that relied on containment and territorialisation to account for and control water led to the negative depiction of evaporation as a loss, and (ii) the historical depth of processes of abstraction and commensuration that are so influential in today's regimes of water accounting and marketisation. The politics of evaporation is identified empirically in the controversy surrounding the management of the Menindee Lakes and the lower Darling River in New South Wales, where efforts to 'save' water according to the logic of efficiency have enrolled atmospheric water into a Basin-wide program to redistribute surface water. The lens of evaporation theorizes a neglected aspect of the materiality of water that is particularly important to the dry, hot parts of the world. It challenges us to rethink the 'cycle' as well as the 'hydro', while providing further evidence of the value of thinking about territory in a material register as volumetric and not areal.
\end{abstract}




\section{Introduction}

Efforts to know and govern water have been confounded by its predisposition to vary its material forms - its 'proclivity to flow, freeze, and vaporize' (Ballestero, 2019: 14; Bakker, 2012). Here we are concerned with the change of liquid water into water vapour via evaporation, a controversial topic for natural philosophers and hydrologists (UNESCO, 1971) with a fraught history of measurement going back to Aristotle (McMahon et al., 2016). Despite this history, which continues today in debates about how it should be measured, we argue evaporation has been under-theorized by geographers and scholars from cognate disciplines.

With notable exceptions (Linton, 2008, 2010; Te Wierik et al., 2019), evaporation has escaped the attention of those who have recently been drawn to the hydrosocial cycle as a framework for understanding relations between water, society and power. The hydrosocial cycle was a reconceptualization of the hydrological cycle developed to counter the prevalence of modern water: the 'particular way of knowing, accounting for and representing water apart from its social context' characteristic of modern hydrological discourse (Linton, 2014: 111; Swyngedouw, 2015). Evaporation has been critically scrutinised by a small number of water governance scholars who have seen it subjected to the efficiency imperative that motivates actors in global institutions such as the World Bank (Shah et al., 2018; Guzman et al., 2017; van der Kooij et al., 2017; World Bank, 2017; Boelens and Vos, 2012). Both bodies of work attend to processes of abstraction and commensuration for they see modernist water management paradigms and their underpinning logics as 'efforts to account for water as if it were the same everywhere, so that it can be compared across places and times' (Guzman et al., 2017: 10).

The event that inspired this article is embedded in such a context of abstraction and commensuration. It concerns a technical struggle over evaporation and water accounting practices in the Lower Darling River region of NSW, in the Murray-Darling Basin (MDB). A contest erupted over the magnitude and value of evaporation from the Menindee Lakes when governments deemed this series of ephemeral low-lying lakes to be a 'water savings project' under a far-ranging set of governance reforms affecting the entire Basin. In the Basin's hydrological discourse and intergovernmental regulatory arrangements, it is not only irrigation activities that are now targeted for water savings. The atmosphere and its moisture have been enrolled in the service of basin-wide 
goals for 'water recovery'. In this semi-arid region less than $6 \%$ of rainfall runs into rivers and streams because the rest evaporates or transpires through plants (Roderick and Farquhar, 2011). The atmosphere is depicted in water management discourse as a force that consumes water and ought to be governed by the norm of efficiency (Jackson and Head, 2020; Guzman et al., 2017; van der Kooij et al., 2017).

The governance reforms in the MDB are being sought via subsidised irrigation efficiencies, buybacks of tradeable water entitlements, and improvements to rules for operating the storages on the Murray River (Grafton, 2019). Experts and decision-makers have established a technical, legal, and physical means of exchanging surface water between catchments and State jurisdictions, while accounting for water redistributions at the Basin scale (Jackson and Head, 2020). The AUS\$10 billion recovery program remains contentious with the amounts of water 'saved' and consequent environmental outcomes vigorously debated, and many rural communities deeply concerned about the uneven socio-economic impacts of taking water away from agriculture and allocating it to the environment (Grafton, 2019; Pittock et al., 2013). Now a space that counts in the governance of the MDB's waters, the atmosphere has been turned into a site for offsetting, enabling governments to reduce water consumption in some places through claimed reductions in atmospheric water that allow consumption of equivalent amounts of surface water to continue in other more productive irrigation districts.

In this context evaporation has become a collective object of concern amongst some irrigators, pastoralists, Aboriginal traditional owners and members of the wider community. What is novel is disputation over methods of measuring evaporation, evaluations of the value of water in different physical states, and reconciliation of promised water 'savings' with the uneven effects arising from the 'losses'. The case raises fundamental questions about scale and territory and their part in longstanding water governance arrangements, distributional justice in water allocations, and the limits of water accounting tools and their underlying logics for knowing and quantifying the value of a substance as fundamental to life as water (Ballestero, 2019).

Engaging with these hydrosocial manoeuvres, this paper discusses the politicisation and governance of evaporation using the concept of hydrosocial territorialisation, stressing the importance of the volumetric dimension to understanding territory and geopolitical processes (Elden, 2013). The 
paper builds upon secondary literature research conducted from 2019 when the authors served as members of a scientific panel established by the Australian Academy of Sciences to examine a water management crisis at Menindee affecting millions of fish, and the wider environment (see Jackson and Head, 2020). To understand how evaporation is treated in water management discourse, legal processes, and allocation decisions, we reviewed documents relating to the Menindee Water Savings Project and its earlier permutations, a Royal Commission into Basin water management in 2018-19, as well as media reports and submissions from residents to other public inquiries.

In the sections that follow we develop the concept of hydrosocial territorialisation using two literatures. The first is work on territory and territorialisation by geographers and political ecologists. We focus on hydrosocial territories (Boelens et al., 2016), together with work that broadens the concept of territory to consider verticality, volumes, the subterranean and atmospheres. The second literature is work in the natural and physical sciences. In this field researchers have also become aware of new governance challenges as they model new flows of water, in different forms and at hitherto unseen scales. We then examine the historical context of evaporation in efforts to understand the water balance and conceptualise the hydrologic cycle. This section unravels the specific measurement logics, definitions, and calculation traditions, or the cultures of knowing and quantifying evaporative water. These historical water accounting logics have shaped the colonial hydrosocial territory of the MDB, leading us to the specifics of the Menindee Lakes Water Savings Project, which we examine as a detailed case in the penultimate section.

As the historical material and the MDB case illustrate, evaporation is more difficult to measure and thus more difficult to regulate than other parts of the hydrological cycle. This makes it particularly subject to selective political processes that privilege some water uses and obfuscate others. We argue that the lens of evaporation theorises a neglected aspect of the materiality of water that is particularly important to the dry, hot parts of the world. In doing so, the evaporative lens challenges ideas of balance and the notion of the cycle itself.

\section{New territorialisations - the hydrosocial and beyond}

Water is 'quintessentially territorial' because flows of water shape the geographical spaces through which they pass (Hoogesteger et al., 2017: 2). Yet standard definitions of territory as bounded 
spaces with control exercised within them are inadequate to conceptualising the profoundly dynamic and mobile nature of water (Elden, 2021). Boelens et al. (2016) extended the concept of the hydrosocial to connect with work on territories and the processes of territorialisation (see also Hommes et al., 2020). For them, hydrosocial territories are 'spatial configurations of people, institutions, water flows, hydraulic technology and the biophysical environment that revolve around the control of water' (p. 1). Just as hydrology conceived and enacted without consideration of the social dimensions can naturalise the politics of water, a key strategy of territorialisation is to make

Water problems and their solutions appear as politically neutral, technical and/or managerial issues which can be 'objectively' solved according to technical knowledge, 'rational water use' and 'good governance' (Boelens et al., 2016: 2).

Boelens et al. (2016) called for research to bring the political nature of such territorialisation to light through the study of everyday water use praxis. Papers in their special issue of Water International (2016, Vol. 41, no. 1) do just that (see also Boelens et al., 2017). For example, Vos and Hinojosa (2016) discussed the water embedded in agricultural or mining products as a new hydrosocial territory which is traded virtually. A variety of tools can be mobilised by nation states and others in the process of hydroterritorialisation; for example, in the case of China's South-North Water Transfer Project, Rogers and Wang (2020) document the role of planning regulations, financial instruments, policies to move people and farms, and discursive imaginings such as 'responsibility' and 'spirit'. Hoogesteger et al. (2016) show, in the highlands of Ecuador, how hydrosocial territories operate across diverse and intersecting scales. As these examples indicate, analyses of hydrosocial territories are especially attuned to scalar dynamics and relations. Hydrosocial territories are enmeshed in other territories and operate at scales that are constantly being redefined, contested and restructured (Swyngedouw, 2015). Different scalar plans and projections for ordering hydrosocial territories may commonly result in the empowerment of certain groups over others and provide arenas for making claims and contesting dominant visions (Boelens et al., 2017).

A further relevance of hydrosocial territories, and one that is highly pertinent to our interest in the politics of evaporation, is the connection to the geographic work that broadens the conventional concept of territory to the vertical, that is, from the land surface and its area to the third dimension. One thread of this research is to go into the subterranean, following Elden (2013), who asked what 
happens if we think about securing the volume rather than securing the area. That paper goes on to discuss verticality, the underground and tunnels, Elden arguing that geopolitics as well as biopolitics has its own processes of calculation and rendering. Given the critical importance of technologies to controlling volumes, Elden construes territory as a 'bundle of political technologies' (such as planning, surveying, mapping, engineering and so on), rather than a flattened, static, landed space (2017: 206). Territory is continually being made and remade volumetrically (Elden, 2013) as it entangled with technology and the materiality of spaces of depth and height. The process is well illustrated by Melo Zurita and Munro (2019: 38) who discuss how agave from the Yucatan Peninsula of Mexico became the most important international rope/twine crop in the late eighteenth and early nineteenth centuries through a form of 'three dimensional control' of the region and its subterranean waterscapes.

\section{Reconceptualising groundwater and atmospheric water}

In a parallel way to how human geographers and political ecologists have stretched their thinking around verticality and volume, a number of scientists (including hydrologists and atmospheric scientists) are recognising empirical challenges to the ways they have conceptualised the movements of water, including both groundwater and atmospheric water. To a significant extent these new perspectives have been driven by enhanced technological capacities to observe and track the movement of water via different types of remote sensing. Rethinking the boundaries and spatial extent of flows of water in all its forms has implications for commonly understood notions such as the watershed, which is defined as 'an area of land draining into a common body of water' (Cohen and Davidson, 2011: 2). So, for example Condon et al. (2020) ask, 'where is the bottom of a watershed?', and Keune and Mirales (2019) challenge the concept of the watershed with their 'watershed precipitation recycling network', which connects atmospheric water.

Atmospheric water flows are now known to vastly surpass global river flows in volume (Keys et al., 2019). There are various terms for these flows, including Atmospheric Rivers (Gimeno et al., 2016) and Aerial Rivers (Weng, 2019). Atmospheric water is also known as 'rainbow water' (te Wierik et al., 2019). We take the example of the Precipitationshed, introduced by Keys (2016), as: 
An area $B$ that is upwind of region A, that provides evaporation for A's precipitation. The extent of precipitationshed is determined by the area that contributes moisture (source region) to a selected region (sink region) (Keys et al., 2017: 16).

In a set of connected papers Keys sets out the principles of Precipitationsheds and demonstrates global patterns of moisture recycling. Increased recognition of land-to-land moisture transport is important because it accounts for $40 \%$ of precipitation over land (and has received much less attention than ocean-to-land moisture transport, which is the other 60\%) (Keys et al., 2019).

In the same way as aquifer use was argued by Melo Zurita and Munro (2019) to be integral to the production of agave, so the concept of a precipitationshed helps to reconceptualise the importance of evaporation as a resource rather than a loss. As Keys et al. (2016) argue, evaporation is generally understood as detrimental to ecosystem services, especially with regard to agricultural production, 'where evaporation is often referred to as a net water loss' (p. 2). But because water leaving the earth's surface as evaporation does not disappear but eventually falls somewhere else as precipitation, they argue instead it is better regarded as an important ecosystem service. Or, more specifically, that Vegetation-regulated Moisture Recycling (VMR), which they define as 'the evaporated water that returns as precipitation downwind that is attributable to vegetation on land' (p. 2) is a critical ecosystem service.

Both the literatures we draw on have recognised that these new concepts and empirical findings complicate the governance of water as a resource (Gupta et al., 2013). Keys et al. (2017) note that while transboundary water governance has been well studied, it has not so far included atmospheric water. A similar argument about the need for governing invisible water resources is made by te Wierik et al. (2019). Based on a literature review, they argue that current water governance arrangements cover 'blue' water (surface and groundwater) only, and that 'green' (the water available to plants in the unsaturated soil increasingly appropriated for agricultural production at the cost of groundwater-dependent natural ecosystems) and atmospheric water also need to be included. Te Wierik et al. make the connection that the new technologies of water harvesting risk creating new hydrosocial territories (after Boelens et al., 2016), raising questions about 'the conditions of access to and control of this water resource' (2019: 13), while Guzman et al. (2017) 
point to the role of capital flows in sustaining techno-scientific advances that marginalise or replace local knowledge of these different waters.

These two literatures highlight several themes of relevance to the Murray-Darling Basin. The Basin is often thought of as a container for surface water only, so it is important to consider how things are different if we include the volumetric spaces through which atmospheric water flows. Through our focus on evaporation, we connect to the atmospheric part of the geographies of territorial power (Elden, 2013). Not all the concepts mentioned above are in practice relevant to Australia; here there are very low levels of VMR, and the concept is much more important for heavily forested parts of the world, adjacent or close to major irrigation areas. But the key point for the purposes of our discussion is the conceptualisation and attempt to think about the spatial distribution of evaporation relationships in all their dimensions, and their connection to land use changes, as well as the implications for water governance. The hydrological cycle becomes even more complex when these spatialities and dimensions are taken into account. We have to consider whether the concept of the cycle is itself too bounded to match the emerging evidence of multidirectional flows of atmospheric water.

We now go on to unravel the networks of expertise, instruments, and measurement logics - the calculative techniques (Elden, 2013) through which evaporation has come to be treated as a loss from a basin. We focus on the important geographic elements of the water balance equation which is a central notion of water accounting that has served as a foundational metaphor for a closed, contained representation of the circulation of water. This idea and its mathematical expression effected the abstraction and commensuration of water as its movement in one form could be inferred from another, as when evaporation from the earth's surface is determined from measurements of changes in soil moisture (UNESCO, 1971). Following Elden (2017), we can see in the evolution of geo-metric techniques for measuring evaporation attempts to control terrain (where terrain can be land, water or some blurring of the two).

\section{Understanding evaporation within a balanced hydrologic cycle}

The dynamic character of water as it circulates 'naturally' through time and space is most famously represented in the scientific construction, the hydrologic cycle, which is the central concept of modern hydrology (Linton, 2010). Linton (2010: 186) traces the early work of experts, particularly 
those from the U.S. who were 'formally schooled in the abstraction and accounting of water', as do Duffy (2017) and Biswas (1970), who focus more on the trajectory of earlier methodological advancements (from the late 1600s). Even though hydrologists and their antecedent natural philosophers had represented the hydrologic cycle in diagrammatic formats, the hydrological way of relating to water was cemented under the organising framework of a mathematical expression, the water balance equation. The water balance enabled quantitative, basin-scale studies of water's fluidity, the objective tally of gains and losses as streams flow under the force of gravity and moisture ascends under the power of the sun, that was to become crucial to the state's rational control of water (Linton, 2010). With these mathematical credentials, hydrology was confirmed by Dooge as a true science whose 'business is to solve the water balance equation' (Klemes 1988; UNESCO, 1971).

The formula for a water balance was presented by American hydrologist Robert Horton who, in 1931, reduced the hydrologic cycle to, in his words, this 'simple, basic fact' (1931: 190):

$$
\text { RAINFALL }=\text { EVAPORATION + RUNOFF. }
$$

Linton (2008) describes the role that Horton's construct and its mathematical formula played in scientific rivalries, for it enabled him to claim the atmosphere as a space to be most capably known by hydrologists, rather than meteorologists who had for centuries claimed the atmosphere as the object of meteorological investigation. For Linton (2010), however, it is the fact that Horton conceptualises evaporation as loss that is of greater importance for what it reveals of the social nature of water. Horton provides a qualification below the water balance equation:

In as much as most persons think of evaporation in a more restricted sense, it is better to define runoff as equal to rainfall minus water losses. Water losses are of three kinds, all evaporative in their nature: (a) interception; (b) transpiration; (c) direct evaporation from soils and water-surfaces) (Horton, 1931: 190).

Linton argues that construing evaporation as loss reveals a critical contradiction in the hydrologic cycle, 'namely that its naturalness is nevertheless suffused with human intention' (2010: 185). Water is regarded as a resource by the experts who were seeking to understand its characteristics 
and dynamics for the purposes of irrigation expansion, and he cites the well-known American engineer who served as the first Director of the United States Reclamation Service, Frederick Newell. Newell devoted a chapter to evaporation in his 1920 book on water resources in which he personified evaporation as a 'robber' taking water at all hours of the night and day, summer and winter. Scientific discussions were yet to give this physical force sufficient weight in his view, yet for Newell (1920: 65), evaporation was 'at the same time ... performing innumerable necessary operations' and it could be put to beneficial use. If it is not, 'we can enjoy the use of only such water as nature may condescend to leave after her toll has been taken' (1920: 65).

Linton interprets the modern use of loss in the following terms:

Evaporation is not a loss to the hydrosphere, to non-human nature, or to the hydrologic cycle. It may be considered a loss only by those for whom the available water flowing in rivers, stored in lakes, or held in aquifers is what really counts - in other words, those for whom water is a resource. The use of the term 'losses' to describe those phases of the hydrologic cycle perceived as being of no immediate use to humans has been very common in hydrological discourse (2010: 185)

Horton was not the first to construe evaporation as a loss, as Linton and others have shown. Pierre Perrault also equated evaporation to a loss in his studies of the Seine catchment of France in 1674, as did Edmund Halley (of comet fame) who in 1686 experimented with another container, this time with a pan of salt water in London (Duffy, 2017). Their use of the term many hundreds of years before the utilitarian idea of natural resources had taken hold gives pause to reflect on a nuance that is missing from Linton's work. To do so requires that we more closely interrogate the water balance idea and its origins in European regimes of calculation and measurement that allowed 'the territory of earth to be connected conceptually and empirically to a wider cosmos' (Heffernan, 2015: 111).

Duffy (2017: 1) argues that a model of balance has been a 'central theme for how scholars of natural history, medieval mathematicians, designers of scientific instruments, and early waterworks engineers viewed the complexities and evaluated the evidence for how water moves in the terrestrial landscape'. The mathematical proposition of the water balance formula 'embodies 
metaphysical assumptions of balance, harmony, and equilibrium' (Ballestero, 2019: 40). In parallel to the more dynamic ideas of precipitationsheds discussed above, but coming from different lines of evidence, Duffy argues that:

In reality, the hydrologic cycle is hardly a cycle at all, because its revolutions are tied to other cycles, quasi-cycles, and random events of the earth system, including orbital earth and solar cycles, regular and irregular oscillations of the ocean-land-atmosphere climate system, and the organization of living things that utilize water in all its phases (2017: 1).

The model of balance also requires the demarcation or containment of a volumetric space. To quantify the balance required understanding the 'systematic interaction of multiple moving parts within a whole' (Kaye cited in Duffy, 2017: 6). This demanded the creation of a complete unit or container - a basin or its experimental representation, the pan, which is an easier object on which to experiment (McMahon et al., 2016).

Early European thinking on the hydrologic cycle had relied on the notion of a water balance before it was represented mathematically. The idea was first developed by French scientist Pierre Perrault in 1674 (Duffy, 2017; Linton, 2010). Perreault, who sought to understand the origin of springs and rivers, conducted experiments in the Seine River region to 'test the sufficiency of precipitation to explain the origin of rivers' (Duffy, 2017: 14). Duffy explains that to compare river discharge with precipitation required that another area be considered, and so, using an assumed measure of the drainage basin area and the mean annual precipitation over the same area, Perrault could 'construct a rough volume of the source and compare it with the annual volume of river discharge leaving the basin' (p. 14). Calculating the difference allowed Perrault to assess the water lost from 'the feeding of trees, plants, grasses, evaporation, useless flows... and other such losses' (Perrault, 1674 cited in Duffy, 2017: 14). Evaporation thus came to be known in relation to the mechanics of streamflow and precipitation of a basin or catchment.

Halley's contribution to hydrology was to seek and find the source of atmospheric water vapour (although the proof came one hundred years later with Dalton) (Linton, 2010). Halley did this at the meeting place of the Fellows of the Royal Society in London where he 
took a pan of salt water, 4 inches deep and 7.9 inches in diameter, and attached it to one end of the beam of a balance having counterpoising weights ${ }^{1}$ on the other side. The water was maintained at a temperature equal to that of 'our hottest summer' by the occasional application of coal fire. It was found, at the end of 2 hours, that 233 grains of water had evaporated (Biswas, 1970: 48).

Halley too needed a container to measure the flows of water and his method did not just rest on the idea of balance, it materially relied on a weighted balance. In these early experiments, we interpret 'loss' as inherent in the notion of balanced territorial processes, where evaporation is a residual variable that is calculated after the more certain components - rainfall and runoff - are calculated (see Evans et al., 2009). Whether one uses a receptacle (a basin, a pan), a mathematical formula, or a balance sheet or ledger to account for water flows (as the latest hydrologic convention does in a water account), water that crosses their material or conceptual boundaries is understood and conceptualised as a loss, no matter how useful one regards that water for human or other purposes. Ideas of balance and loss are co-constitutive, a point we return to below.

This was the era of measurement and comparison in which the elements of scientific practice were born. These methods and particularly a quantitative account of a nation's water was 'the most important prerequisite for achieving scientific management' that could effect the complete control of units of water (Linton, 2010: 151). Linton (2010) draws on Scott's notion of legibility (1998) to show that accounting for water, its stocks and flows, and reducing it to a framework and to terms upon which governments can act, was critical to facilitating rational management. From here the quantitative approach to water that had been a feature of scientific endeavour was adopted by the state (Linton, 2010). American governments devoted a great deal of attention to the project of calculating water flows, as did the governments of the Murray-Darling Basin (Jackson and Head, 2020). Engineers and meteorologists took abstract, mathematical stock-takes (Linton, 2010), calculating the water balance as water flowed across land, seeped into cracks and crevices or vaporised through plants or the atmosphere. According to historians of science, such as Dear (2001: $55)$, these acts of measurement rendered 'the differences between things ... to simple quantifiable

\footnotetext{
${ }^{1}$ Halley used a now obsolete unit of weight, a troy, to calculate a cubic foot of water and from there the rate of inches evaporated per hour (Biswas, 1970).
} 
proportions'. Linton points to another consequence that is pertinent to this paper - 'the quantitative view of water renders it naturally scarce' (2010: 154, italics in original). Water could now be seen to have a definite supply and a definite limit. Water, 'in other words, was now susceptible to scarcity, which made it imperative that it be managed efficiently' (Linton, 2010: 154).

Beyond the link between a formula, a balance, or ledger, to devices that enable the processes of abstraction and commensuration, where one volumetric unit of water can be exchanged for another in the pursuit of efficiency for instance, the hydrologic cycle contains another important idea. If we relate the model of balance (Duffy, 2017) to a metaphor of temperament, as does Linton in a paper that questions the validity and sustainability of the hydrologic cycle, we can see the power of the assumption of the universality of humidity:

The hydrologic cycle thus embraces all water, but it hardly treats all waters fairly: Its balance and symmetry, its even-tempered regard for evaporation, condensation, precipitation and runoff, is incongruous with the experience of water in deserts, polar regions, or places subject to pronounced hydrological variability (seasonal or annual fluctuations in precipitation) (Linton, 2008: 632).

In those regions that depart from the temperate model of flows of water upon which the hydrologic cycle was built, an imbalance between the variables, evaporation and runoff, weakened the prospects for agriculture and justified state interventions in regulating streamflow. This can be seen clearly in the first hydrologic assessment of the Darling River region that underpinned commitments to utilise the Basin's rivers for irrigation. To appraise accurately water's economic potential, colonial agents of the late 1800s and early 1900s needed detailed knowledge of river discharge, requiring hydrologists to extend their inquiry beyond the channel to the river's catchment area. As we show elsewhere (Jackson and Head, 2020), engineering expertise was called on in a colonial territorial effort to secure technical control via water measurement and accounting methods that could determine the Basin's water balance. The first map of its drainage area, prepared by Irish hydrologist Hugh McKinney, rendered those areas that contributed to stream discharge as 'effective catchment' and the arid areas that did not, as 'ineffective catchment'. The Darling River ran entirely through the area deemed ineffective for its imbalance between evaporation and runoff. Over a hundred years later the region's 'excessive' rates of evaporation are under a different kind of scrutiny and 
many in the local community are contesting the depiction of local hydrological processes as inefficient.

\section{The Murray Darling Basin's politics of evaporation - the Menindee Lakes Water Savings Project}

Elsewhere we describe the governance context in which the dispute over evaporation sits, particularly the reform of water laws and the introduction of a statutory, multi-jurisdictional Murray Darling Basin Plan (Jackson and Head, 2020). Here we briefly cover similar ground before turning to the specifics of the Menindee case.

\section{$\underline{\text { Governance context }}$}

In the 1990s Australian governments transformed water law and policy in response to excessive extraction, declining water quality and ecological degradation. In line with neoliberal principles, this entailed restructuring rights to water, establishing water trading to encourage efficient use and resetting the balance between irrigated agriculture and the environment. Basin governments separated land and water titles to enable trade and they committed to legally protecting environmental flows (Pittock et al., 2013). Diversion limits were introduced over two stages, first in 1995, when water use across most of the Basin was capped and, second, following a serious drought from 2000-2010, when the Basin Plan commenced a wind back of water extractions across the entire Basin by about 25\%. In 2012 the Basin Plan set what is referred to as the Sustainable Diversion Limit (or SDL) (Grafton, 2019). The SDL is $10,873 \mathrm{GL}$ per year (on average) for the Basin as a whole. To get to this SDL by 2019, the Australian Government had to recover 2,750 GL of water for the environment from irrigators. Governments also allocated more than 10 billion dollars (Aus) to purchasing entitlements and to investing in infrastructure projects to reduce agricultural water use (Pittock et al., 2013; Grafton, 2019). Water management coordination became the responsibility of the Murray Darling Basin Authority (MDBA).

The Basin Plan includes an SDL Adjustment Mechanism (SDLAM) that allows an increase in the SDL of up to $650 \mathrm{GL}$ of water from 'supply measures', and $450 \mathrm{GL}$ of additional water from 'efficiency projects' (MDBA, 2017: 1). According to the MDBA, this allows governments to 'optimise the outcomes achieved by the Basin Plan' and it will 'make sure all water is used efficiently, and to its full effect' (MDBA, 2017: 2). 'Supply measures' increase the 'the supply of water' (or quantity of water available to be taken) and these include building or improving river or water management 
structures and changes to river operating rules. Whereas 'efficiency projects' entail making 'consumptive water use more effective and efficient' (MDBA, 2017: 11).

To be effective, these engineering fixes and other efforts to recover water from irrigators require quantification through measurements, calculations, estimates and system modelling. Grafton (2019: 125) has been particularly critical of the absence of 'comprehensive physical accounting' of the Basin that would encompass the water extracted, the water transpired and evaporated, and the 'non-consumed' water that returns to the ground or river channel after being used by irrigators (see also Ballard et al. 2015). To do so would bring into play contentious water use practices widely practised in the northern Basin, such as floodplain harvesting (collecting water flowing over floodplains) which alters surface water flows and evaporation rates but is not licenced or captured well in reporting diversion statistics (AAS, 2019; Slattery and Johnson, 2021). Investment in private storages upstream of Menindee has grown markedly in recent decades, to the extent that their storage capacity rivals that of headwater dams ${ }^{2}$ (Webb, 2007; AAS, 2019; Slattery and Johnson, 2021). Evaporation from them is regarded by hydrologists as a major cause of loss of water from 'the system' (Webb et al., 2007: 2). Without appropriate and timely measurements, including 'evaporative losses' from storages of harvested water, water balances of the MDB will remain incomplete, and proper assessment of water recovery actions will be impaired (Grafton and Williams, 2019).

\section{The Menindee Lakes Water Savings Project}

The Menindee Lakes were reconfigured as water supply infrastructure in the 1950 s to meet interstate commitments to water sharing across the MDB (Jackson and Head, 2020). The Menindee Lakes storage scheme entails a series of small dams, weirs, regulators, channels and levees designed to retain Darling River flood waters. Flood waters can be stored when the water level is raised to 12 metres above bed level and Lake Tandou, Lake Bijijie, Lake Balaka and Lake Malta are inundated. These combined lakes and the inundated floodplain behind the main weir are known as Lake Wetherill. An inlet regulator allows water to pass from Lake Wetherill to Lake Pamamaroo, where it

\footnotetext{
${ }^{2}$ Under the inter-governmental agreement that governs State Government water shares, the volumes that evaporate from public storages (referred to in the Water Act 2007 as 'losses', see s. 110) are tallied and apportioned, as is water that evaporates from river channels as it travels downstream of dams (Ballard et al. 2015).
} 
can be stored to a maximum depth of $4.8 \mathrm{~m}$. Water can then be transferred through a channel from Lake Pamamaroo to Lake Menindee, where it can be stored to a depth of $5.4 \mathrm{~m}$. Water can also be transferred to the Darling River channel through regulators from Lake Wetherill, Lake Pamamaroo and Lake Menindee, as well as from the main weir. The operational objectives of lake management are to minimise evaporation, maximise storage volumes, maximize water quality, maximise ability to supply users, and mitigate floods where possible (AAS, 2019). The lakes are considered a significant 'environmental asset' in arid Australia, valued as habitat for 170 species of bird, many of which are migratory, and several of which are threatened or rare and protected by State and Federal environmental laws (SKM, 2010). Menindee Lakes are also listed on the Australian Directory of Important Wetlands and part of the lake system is contained by the Kinchega National Park.

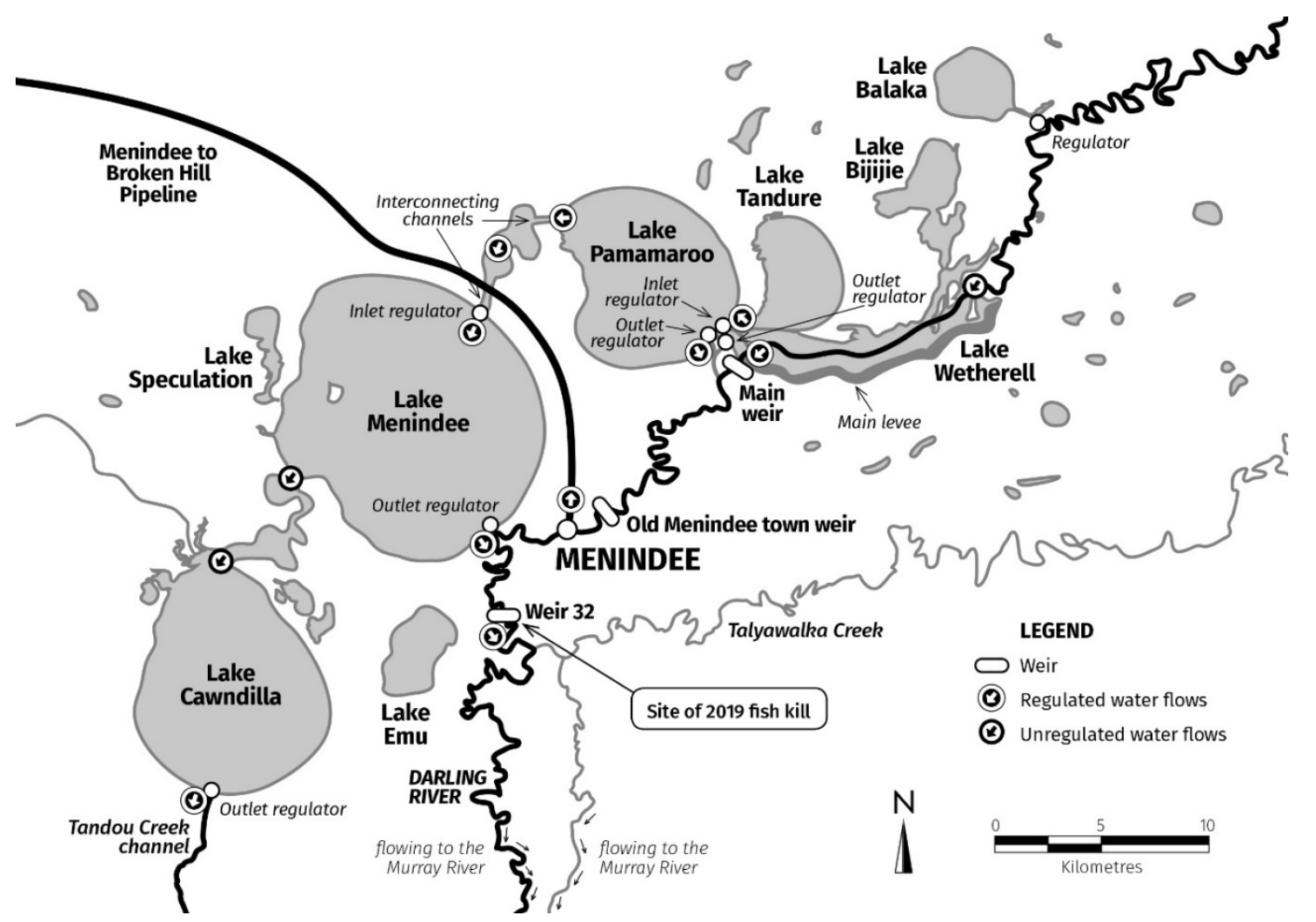

Figure 1 Map of Menindee Lakes and lower Darling River.

Source: Adapted from Vertessy et al. (2019) by First Class Communications

The Menindee SDLAM project is the latest of a number of government investigations into ways of reducing evaporation undertaken over recent decades. In 2017 NSW proposed to re-engineer Menindee Lakes as its major contribution to meeting that jurisdiction's 'water savings' commitment 
under the Basin Plan (MDBRC, 2018). For Basin governments, the project represented an 'opportunity to account for the equivalent environmental outcomes achieved from the improved management of the Lake system and more efficient use of water by environmental water holders' (Blackwatch Consulting, 2017: 9). A business case for the project states that 'The collective view of the jurisdictions at that time was that more needed to be done to capture a greater share of the well documented system losses at Menindee' (Blackwatch Consulting, 2017: 34). NSW then considered the lake system, with its large surface area to volume ratio, a promising candidate for the 'water savings' program on the premise that 'evaporative water loss from the Menindee Lakes could be reduced [and] significantly more water could be made available for the environment' (NSW Department of Industry, 2018: 7). Estimates of evaporation from the lakes in the business case varied between $72 \mathrm{GL}$ and $116 \mathrm{GL}$, depending on which elements of the project were included in the modelling of these 'savings'. According to Ford (2020), this modelling is not publicly available, nor could it be retrieved through an NSW Parliamentary Order she made as part of her study. Ford (2020) identifies a water savings black-box ${ }^{3}$ and notes the absence of peer-reviewed scientific analyses (see also AAS, 2019).

Other studies have observed that the lower Darling region has very high evaporation rates, from 2 $\mathrm{mm}$ a day in winter to up to $20 \mathrm{~mm}$ per day in summer (Green et al., 2012)). To minimise evaporation, it has been long-standing practice to prioritise releases from Menindee Lakes above other storages on the Murray River. Water managers consider dams such as Dartmouth and Hume (on the upper Murray) as 'more efficient' because they do not have the high evaporation rates of the Menindee Lakes (Glyde, 2019). A table published in a 'fact sheet' by the NSW water agency compares evaporation rates from southern Basin storages, concluding that 'If evaporative loss from the Menindee Lakes is reduced there would be more water available in the system.'

\footnotetext{
${ }^{3}$ The twenty-two structural and operational measures designed to achieve projected water savings do not contain explanations of the contribution each would make to the total.
} 


\begin{tabular}{|c|c|c|c|c|}
\hline Storage Name & $\begin{array}{l}\text { Storage surface } \\
\text { area }(\mathrm{Ha})\end{array}$ & $\begin{array}{l}\text { Storage } \\
\text { volume (GL) }\end{array}$ & SA: V & $\begin{array}{l}\text { Net } \\
\text { evaporation } \\
\text { loss (GL/yr) }\end{array}$ \\
\hline Blowering Dam & 4,300 & 1,631 & 0.003 & 6.3 \\
\hline Burrinjuck Dam & 5,500 & 1,026 & 0.005 & -2.0 \\
\hline Dartmouth & 6,380 & 3,856 & 0.002 & 0.5 \\
\hline Eildon & 13,832 & 3,334 & 0.004 & 3.8 \\
\hline $\begin{array}{l}\text { Hume Dam } \\
\text { Storage }\end{array}$ & 20,091 & 3,005 & 0.007 & 76.4 \\
\hline Lake Victoria & 12,200 & 677 & 0.018 & 130 \\
\hline Menindee Lakes & 45,700 & 1,731 & 0.026 & 399 \\
\hline
\end{tabular}

Table 1: Surface area to volume ratios and evaporation from various storages in the MDB Source: NSW Government Factsheet: Measurement and comparison of evaporation in water storages, Department of Industry, 2019.

Proposals to reconfigure the way in which the lakes are operated have been in existence for a number of years but here we focus on the efforts to manage evaporation and the consideration given to Menindee's role in Basin water flows. The technical documents we examined follow the narrative of the 'water saving story' described by van der Kooij et al. (2017) in relation to irrigation efficiency discourse. This 'story', often promulgated through the promotion of modern and efficient irrigation technologies, suggests that more water will be created, thereby 'satisfying demand or demands of new users without having to take water away from others' (van der Kooij et al., 2017: 68). For instance, a 2010 report of an early version of the water savings project at Menindee stated that 'The six schemes focus on reducing evaporation in the MLS [Menindee Lakes System] to provide river flows that would not otherwise have been available' (SKM, 2010: 72). Later, the consultants explain that 
Reduced evaporation from the MLS has little or no economic or environmental utility in its own right. However, reduced evaporation can provide additional, previously unavailable, downstream river flows (SKM, 2010: 81).

In this report, these 'additional' flows were then valued using prices for traded water entitlements as a proxy. The most recent plan is to reduce the surface area of the lakes (by decommissioning Lake Cawndilla as a storage) and draw down water levels more quickly, by releasing higher flows from the main weir (MDBA, 2017) ${ }^{4}$. 'Saving' water in the order of $100 \mathrm{GL}$ p.a. will require engineering works, changes to lake operating rules, and socio-economic 'adjustments' that include 'removing irrigation and town water supply demands' (Blackwatch Consulting, 2017: 9). The reconfiguration of the lakes is required to be finished by 2024 or else more water will be required to be removed from production in other parts of the Basin to meet Basin-wide targets for water recovery for the environment. To assist NSW in the endeavour, the Commonwealth Government purchased from the corporation holding Australia's biggest water portfolio a large irrigation licence at Menindee (Gooch and Beilharz, 2017). Claiming that 'this water acquisition is not just about the gigalitres' the Agriculture Minister drew attention to the wider gains when he said, 'It is about the significant strategic, long-term benefits it will deliver for irrigators and communities right across the southern basin' (Gooch and Beilharz, 2017).

\section{Local responses to the Menindee project}

There has been widespread community concern and local opposition to the Menindee Lakes Project, especially its potential environmental and cultural heritage impacts. Through a variety of channels and over a number of years, members of the local community have challenged the scientific claims of water agencies in attempts to resist the decommissioning of the Lakes (see, for example, Vertessy et al., 2019). The project was described by Bret Walker, the recent Royal Commissioner who inquired into water management in the Basin, as a 'dispiriting instance of environmental infrastructure project planning' (MDBRC, 2018: 316).

\footnotetext{
${ }^{4}$ Other elements include changes to lake operating rules and decoupling the town of Broken Hill from the Menindee Lakes via the construction of a new pipeline to transport water from the Murray River (see Figure 1).
} 
A local group, the We Want Action Group, argued in 2011 that the 'great evaporation hoax' was an orchestrated campaign by upstream cotton growers to 'focus attention on evaporation losses from Menindee Lakes' (Hutton, 2011: no page number). Cotton has grown rapidly in the northern basin over the past thirty years, and according to a submission to the draft Basin Plan from the We Want Action Group, this powerful industry was successful in lobbying for 'ways to engineer evaporation savings' at the lakes. In the same submission, this group highlights the report from 2007 cited above (Webb et al., 2007) that estimated that 'Evaporation losses from the Menindee Lakes (393 Gigalitres/annum) are much less than total evaporation from on farm water storages upstream of Menindee' ( $\mathrm{p} 20)$. According to the We Want Action Group, the privately held dams and large ring tanks (constructed by building earth walls and trapping floodwaters) 'represents a transfer of water from the publicly owned Menindee Lakes to private lakes upstream. Water is generally pumped into these ring tanks from summer rains, and held until cotton planting in October, and later cotton watering. Evaporation rates are high' (2011: no page number).

The Action Group challenged the evaporation rate claimed by government agencies (see Figure 2), saying it is an

... 'average', but over what period, and is it relevant to the present or the future? Since 2002 Lakes Menindee and Cawndilla have been dry, i.e., no evaporation losses are possible. Lake Wetherell and Pamamaroo have varied from full to dry. When full, these lakes, combined, hold about $540 \mathrm{GL}$. Over the last 6 years evaporation would have been less than $100 \mathrm{GL}$ per year. With the huge increases in on farm storages upstream, and with climate change, it is likely that Lakes Menindee and Cawndilla will fill rarely, if ever. If huge amounts of money are spent to reduce evaporation there, it will be wasted.

What are the motives of the cotton growers who want changes to Menindee Lakes? First, it diverts attention from their own plundering of the Darling River Basin. Second, if water savings are made at Menindee Lakes, they figure that they won't have to let as much water go past their cotton farms. They will clamour to be given a share of the water savings. This will mean less water in the rivers, all the way from the cotton farms to Menindee Lakes... 
Some politicians and irrigator groups have over the past few years singled out the Menindee Lakes as a scapegoat for the problems of the Darling River by describing them as "just big evaporation pans" and calling for their decommissioning (Hutton, 2011: no page).

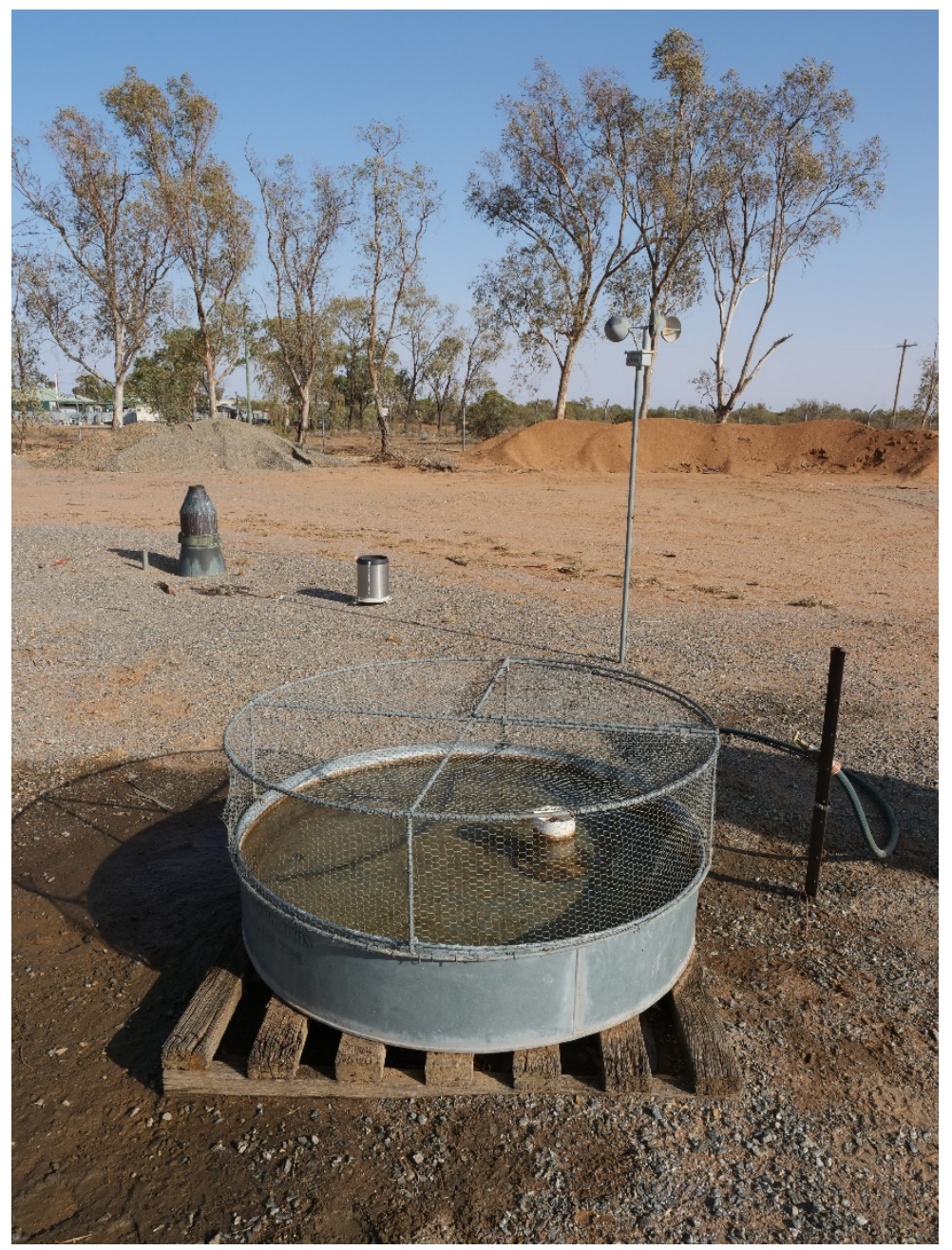

Figure 2 Evaporation pan used by NSW Office of Water, Menindee, NSW

The local caravan park manager, Tim Walter, who was then a member of a stakeholder consultative committee tasked with finding long-term solutions for the far west's water supply, said:

They also talk about evaporation like it's a dirty word - but past rainfall records show that totals go up when the lakes have water in them. Evaporation creates rain. When the lakes were full, we used to watch storm-after-storm come through. Now, the storms bypass the 
lakes, because they're so dry. We are going to need a very big flood for this system to recover (Fogden 2015).

Note that the interpretations by local residents that the lakes have their own local evaporation regimes and weather patterns is due to the sheer size of the lake system. The larger individual lakes are more than $10 \mathrm{~km}$ across, and the system is approximately $50 \mathrm{~km}$ from end to end (Figure 1).

A Royal Commission into the management of the MDB heard evidence from a former NSW and Commonwealth water manager who attempted to turn the idea of water 'losses' on its head. Bill Johnson (2018) drew attention to the limitations of 'temperate' ideas about water flows - thinking, planning, and allocating water based on long-term averages (which he suggested was an idea that was good for irrigators). He also questioned the technical assumption one can 'run the system' like a financial institution - with a tight balance sheet where losses and savings can be precisely identified:

MR JOHNSON: ... long-term averages obscure all of the practical day-to-day, year-on-year extractions, environmental needs - soakage, seepage, evapo-transpiration, are all put into losses in many cases ... this environmental flow from - that has got - just crept to Menindee ... it only got there because there were so many losses on the way ${ }^{5}$. And - and those flows were the flows that replenished waterholes, saved fish, rejuvenated the riparian.

THE COMMISSIONER: So you're concerned that losses is apparently a category that includes saving fish.

MR JOHNSON: ... I seem to have made no progress in ... getting people to stop using it. It has been a bug bear of mine for a quarter of a century (2018: 1402).

Grazier Rob McBride (2018: 1929) also challenged the notion of the Darling River being an 'ineffective' river when he highlighted its capacity to sustain life for 60,000 years:

\footnotetext{
5 Johnson is referring to a release of environmental water from upstream dams that made its way to Menindee over 3 4 months during 2018. At the time the river was dry in parts but wet in others because of recent rainfall.
} 
So if it wasn't particularly a really good river, I don't think 60,000 years of civilisation with the Barkandji Nation ${ }^{6}$ would still be there. So it has just been drawn into the calculations. Without a doubt, Commissioner, yes, evaporation happens. Evaporation has to happen. If it doesn't happen, we don't get rain. We don't get clouds. There's no question about that. It's a nobrainer.

The 'leakage' afforded by the Menindee Lakes is raised as a benefit by McBride, for what it provides to the groundwater systems of the region:

But it's just that it has been extrapolated out of all proportions by comparing six inches of water with seven metres of water and taking no calculation into the aquifer that feeds, you know, hundreds of thousands, if not millions of hectares of area in the western division of New South Wales because that water has to go underneath an area somewhere in the vicinity of 1000 kilometres, maybe 1,000 kilometres below five or 10 kilometres. That's a large vast area of underground water supplies that is not in the calculation (2018: 1929).

The three-dimensional relationships between evaporation, seepage and conveyancing water are also recognised in studies that call for more comprehensive forms of water accounting. Critics want to see government methods that measure evaporation account for seepage, as well as the amount of water required to wet dry lake beds, sustain lake life and keep the river downstream flowing (Slattery and Campbell, 2019). Decisions that may disrupt the pattern of drying and wetting need to account for water required to wet the lakebed and to keep it functioning as a lake, as well as a source of water for all life downstream. A more fulsome reckoning should consider that 'nearly an equal amount of water is required to enable the lakes to start refilling after they have dried out ... it seems equally as 'inefficient' to completely drain the lakes, because several hundred gigalitres (hundreds of thousands of megalitres) are required to wet the dry lakes beds before the Lakes will hold water and refill' (Slattery and Campbell, 2019: 30).

\footnotetext{
${ }^{6}$ The name of the largest Aboriginal Traditional Owner group of the western NSW region through which the Darling River runs.
} 


\section{Discussion}

The evidence presented above shows that the local residents of Menindee contest how evaporation is conceptualised, how it is measured and the implications of conceptualisation and measurement for water management decisions. They draw attention to weaknesses in using efficiency terms as the measure of the productivity of water and the assertions of irrational water use, resisting the discourse and its normative judgement. Some believe that water managers are over-estimating evaporation from Menindee and that these calculations are being used to deprive them of water rights and potentially destroy or degrade the lakes. Water savings are perceived as a territorial claim (a hoax) perpetrated by upstream users (e.g., cotton farmers) who are unwilling to reduce their consumption of water and even plan to increase it, or others who support these powerful interests. The territorial nature of the conflict over evaporation is ever present in the local critique of a program that 'captures losses' to 'save water'. Efforts to draw attention to the scalar effects of moving from analysis at localised sites like a lake system to the river basin, and across three dimensions of a fluid and dynamic earth, similarly stem from a concern with territorial processes of boundary making and containment.

One of the means by which water managers are understood to take water away is to not consistently take account of evaporation, as only public storages are subjected to the 'efficiency test'. Private storages are treated differently, their location is not made known by government agencies and their evaporation rates are poorly understood (Slattery and Campbell, 2019; Grafton and Williams, 2019). Water management agencies consider that the water that evaporates from private water storages can be effectively accounted for at the pump through licencing regulations. Any 'losses' from private dams are borne as a private cost to the landowner, not treated as an inefficiency deserving state regulatory action. Still others point to numerous flaws in the regulation of upstream water use (Grafton, 2019; AAS, 2019).

Basin water governance systems are also criticised by Menindee community members for ignoring local history, context, and interests, particularly the knowledge of Aboriginal traditional owners and local water users (AAS, 2019; Vertessy et al, 2019; McBride, 2019). Menindee's community is sceptical and does not trust 'the information being used to make decisions about river operations and water management' (Vertessy et al., 2019: 30). Reported flow rates (of vaporised or liquid water) are disputed because they do not align with on-ground observations by locals or their 
awareness of the multi-dimensional character of water flows. While others, such as the Royal Commissioner into the Murray-Darling Basin (MDBRC 2019; see also Ford 2020) expose the lack of rigor in estimating water savings and efforts to prevent public critique of any underpinning calculations of evaporation. In April 2020, representatives of the Menindee community walked out of the government-led consultation process for the water savings project (ABC, 2020) and in March 2021, the NSW Department of Planning, Industry and Environment announced that discussions on the project will be suspended (The Land, 2021).

In public statements made by residents from the lower Darling River we can see that people have their own logic or rationality for evaluating the value of water flows and they contest the conceptualisation of evaporated water as waste, for example in the relationship between evaporation and seepage. They point to what they perceive to be logical flaws in how water agencies and other technicians interpret the hydrologic cycle. From their perspective, 'losses', or localised depletions from a closed system, serve a function, perhaps many functions, for they induce or bring about gains in rainfall or groundwater recharge for example, if not locally then somewhere else. In defending their hydrosocial territories, they are acting on the insight of irrigation specialist PalaciosVelez (1994) who argues that 'water that is lost is not always necessarily wasted' (see also Guzman et al., 2017).

The Menindee case reveals attempts by local actors to engage with and elevate the importance of the materiality of water, thereby resisting the processes of abstraction and commensuration that underpin modern ways of relating to water and are effected by techniques of water accounting (Jackson and Head, 2020). The experience of Menindee locals illustrates the broader issue of how evaporation is governed in the Basin. That governance has little transparency, yet it contains deeply embedded assumptions: evaporation is a loss, and conceptualising it thus allows water to be moved from one part of the Basin to another; 'public' evaporation is treated differently to 'private' evaporation; water is primarily for agricultural usage, so efficiency is prioritised over community needs and the environment.

The choices in our case centred on which water bodies and their atmospheric flows are to be counted and regulated (a question that lies at the heart of the literature on atmospheric waters reviewed above), which regions will win or lose from water 'saved' in one location rather than 
another, and whose knowledge and expertise is to prevail in determining the distribution of not just surface waters, but atmospheric waters as well.

\section{Conclusion}

In this paper we have shown evaporation to be a hydrological concept that is not neutral but is rather an arena for organising hydrosocial territory. A social interpretation of the science of evaporation and water accounting technologies revealed the origins of the negative depiction of evaporation as a loss and highlighted the historical depth of processes of abstraction and commensuration that are so prevalent and influential today. We showed how regulating surface water flows alone shaped the colonial hydrosocial territory of the Murray-Darling Basin, until this century when atmospheric water became valuable under market-based instruments that include offsetting. We can see in the Menindee case that evaporation has retained its illogical formulation as a 'loss' (Linton, 2010), but there has been a distinct shift in the coding of the value of water (Kirsch, 2013). Stored water that was previously regarded as lost to irrigators at the site of its transformation into vapour is valorised as useful, when accounted for at the scale of a volumetric Basin.

The politics of evaporation is identified empirically in the controversy surrounding the management of the Menindee Lakes and the lower Darling River and efforts to 'save' water according to the logic of efficiency. So far, these efforts have not resulted in a balanced appraisal of the region's aridity/humidity, what benefits the high rates of evaporation might bring and how they sustain the continuity of life based on these hydrosocial relations. Researchers working on concepts like the precipitationshed are trying to bring to light such 'services', and in doing so, challenge the unity of the hydrologic cycle.

In the Menindee Lakes Water Savings Project an array of political technologies has enabled claims to be made to the atmosphere and to control the terrain of the Basin. Without any public debate, the MDB has gone from being treated as a 'watershed' defined by surface water flows to something else, yet without the scientific input into more comprehensively understanding atmospheric flows as well as other vertical flows like seepage. Residents have contested this act of atmospheric territorialisation using alternative understandings and experiences and have attempted to defend 
water-based territories against the different scale of resource governance that the State and Federal water agencies are seeking to impose.

In examining the dominant neoliberal discourse of water saving and its water accounting devices in an influential empirical case (particularly its scalar assumptions and foundations), our contribution has been to show how 'water territories, their configurations and spatial scales' are reorganised over time (Boelens et al., 2017: 32). By revealing the repertoire of technologies (the political, legal, scientific and technical) used to claim the atmosphere and its waters as a political space, we have affirmed the value of thinking about volume (the complexity of height and depth) as a dimension that states, and others act on in transforming territories. The territory of the MDB is not a simple bounded area demarcated by surface water flows. Efforts to alter evaporation at one site will affect flows of atmospheric and surface water, as well as land uses and livelihoods at other sites, including through any changes to groundwater. A volumetric perspective therefore requires understanding how the vertical relates to horizontal and subterranean socio-political and material processes. It also warrants attention to processes of calculation and measurement, or the calculability implicit in the volumetric (Elden, 2021).

Scholarship on the hydrosocial cycle has focused on the liquid part of the hydrological cycle, which is also privileged in water resource management. In focusing here on evaporation and the volumetric we have extended such scholarship to the more diverse dimensions of the materiality of water, which are particularly important to the dry, hot parts of the world. We have also connected a central, foundational hydrological concept (the water balance) to contemporary efforts to know water as a financial asset, and this will be an important area of inquiry for future research. The lens of evaporation, and its connection to historical models of balance, require us to rethink the 'cycle' as well as the 'hydro', while providing further evidence of the value of thinking about territory in an explicitly material register as a volume not an area. 


\section{References}

Australian Academy of Science (2019) Investigation of the causes of mass fish kills in the Menindee region NSW over the summer of 2018-2019. Australian Academy of Science, Canberra.

ABC (2020) Controversial Menindee Lakes proposal labelled a waste of time as stakeholder group puts talks on hold. https://www.abc.net.au/news/2020-08-20/controversial-menindee-lakeswater-saving-darling-river/12577088

Ballard A, Garland N and Hannan G (2003) Monitoring and accounting for water trade in the Murray-Darling Basin. Australasian Journal of Water Resources 7(1): 49-56.

Ballestero A (2019) A Future History of Water. Durham: Duke University Press.

Bakker K (2012) Water: Political, biopolitical, material. Social Studies of Science 42(4): 616-623.

Blackwatch Consulting (2017) Menindee Lakes Water Savings Project, Phase 2 Business Case, June 2017, Report to the NSW Department of Primary Industries.

Boelens R and Vos J (2012) The danger of naturalizing water policy concepts: Water productivity and efficiency discourses from field irrigation to virtual water trade. Agricultural WaterManagement 108: $16-26$.

Boelens R, Crow B, Hoogesteger J, Lu F, Swyngedouw E and Vos J (2017) Hydrosocial Territories and Water Equity. London: Routledge.

Boelens R, Hoogesteger J, Swyngedouw E, Vos J and Wester P (2016) Hydrosocial territories: A political ecology perspective. Water International 41 (1): 1-14.

Biswas A (1970) Edmond Halley, F.R.S, hydrologist extraordinary. Notes and Records of The Royal Society 25(1): 47-57. 
Cohen A and Davidson S (2011) An examination of the watershed approach: Challenges, antecedents, and the transition from technical tool to governance unit. Water Alternatives 4(1): 114.

Condon L, Markovich K, Kelleher C, McDonnell J, Ferguson G and McIntosh J (2020) Where is the bottom of a watershed? Water Resources Research 56(3), e2019WR026010.

Dear P (2001) Revolutionising the Sciences: European Knowledge and its Ambition, 1500-1700. Princeton, NJ: University of Princeton Press.

Duffy C (2017) The terrestrial hydrologic cycle: An historical sense of balance, WIREs Water 4:e1216. doi: 10.1002/wat2.1216

Elden S (2013) Secure the volume: Vertical geopolitics and the depth of power. Political Geography 34: 35-51.

Elden S (2017) Legal terrain -the political materiality of territory. London Review of International Law 5, 199-224.

Elden S (2021) Indeterminate and changing environments: Law, the Anthropocene, and the world (https://icelawproject.files.wordpress.com/2014/08/s-elden.jpg, accessed January 2021.

Evans R, Murrihy E, Bastiaanssen W and Molloy R (2009) Using Satellite Imagery to Measure Evaporation from Storages - Solving the Great Unknown in Water Accounting. Paper presented at the Irrigation and Drainage Conference 2009, Irrigation Australia Ltd, Swan Hill, Vic, Australia, 18 21 October 2009.

Fogden A (2015) Menindee Lakes faces dry future, Stock Journal, 28 April, https://www.stockjournal.com.au/story/3367991/menindee-lakes-faces-dry-future/

Ford Z (2020) Decision-making for Menindee Lakes in the Murray-Darling Basin - drivers and consequences. Honours Thesis, UNSW: Sydney. 
Gimeno L, Dominguez F, Nieto R, Trigo R, Drumond A, Reason C ... and Marengo J (2016) Major mechanisms of atmospheric moisture transport and their role in extreme precipitation events. Annual Review of Environment and Resources 41: 117-141.

Glyde P (2019) Tragedy of fish deaths in drought shows need for Basin Plan, https://www.mdba.gov.au/media/mr/tragedy-fish-deaths-drought-shows-need-basin-plan

Gooch D and Beilharz N (2017) Cotton grower Tandou to sell water entitlements, convert NSW farm to lamb business, ABC, 22 June, https://www.abc.net.au/news/2017-

06-21/cotton-grower-tandou-to-sell-water-entitlements-convert-farm/8639968.

Grafton R (2019) Policy review of water reform in the Murray-Darling Basin, Australia: the "do's" and "do'nots". The Australian Journal of Agricultural and Resource Economics 63: 116-141.

Grafton R and Williams J (2019) Thirst for certainty: the urgent need for a water audit of the MurrayDarling Basin. Farm Policy Journal Winter: 14-22.

Green D, Ali A, Petrovic J, Burrell M and Moss P (2012) Water resources and management overview: Lower Darling River Catchment, NSW Department of Primary Industries, Sydney.

Gupta J, Pahl-Wostl C and Zondervan R (2013) 'Glocal' water governance: a multi-level challenge in the anthropocene. Current Opinion in Environmental Sustainability 5(6): 573-580.

Guzman C, Verzijl A and Zwarteveen M (2017) Water footprints and 'pozas': Conversations about practices and knowledges of water efficiency, Water 9(16), doi:10.3390/w9010016

Heffernan M (2015) The birth of territory: A review forum. Journal of Historical Geography 50: 109188.

Hommes L, Boelens R, Bleeker S, Duarte-Abadia B, Stoltenborg D and Vos J (2020) Water governmentalities: The shaping of hydrosocial territories, water transfers and rural-urban subjects 
in Latin America. EPE: Nature and Space 3(2): 399-422.

Hoogester J, Vos J, Boelens R, Crow B, Lu F and Swyngedouw E (2017) Introduction: interweaving water struggles, the making of territory and social justince. In: Boelens R, Crow B, Hoogester J, Lu F, Swyngedouw E and Vos J (eds) Hydrosocial Territories and Water Equity: Theory, Governance and Sites of Struggle. Abingdon and New York: Routledge, pp. 1-7.

Horton R (1931) The field, scope, and status of the science of hydrology. Transactions, American Geographical Union 12: 189-202.

Hutton, M (2011) Submission from the We Want Action Group to the Murray-Darling Basin Plan. Jackson S and Head L (2020) Australia's mass fish kills as a crisis of modern water: Understanding hydro-social change in the Murray Darling Basin. Geoforum 109: 44-56.

Johnson W (2018) Witness statement 25 July 2018 to the Murray-Darling Basin Royal Commission, Adelaide: 1380-1455.

Keune J and Miralles D (2019) A precipitation recycling network to assess freshwater vulnerability: Challenging the watershed convention. Water Resources Research 55(11): 9947-9961.

Keys P (2016) The precipitationshed: Concepts, methods, and applications. PhD Thesis, Stockholm Resilience Centre, Stockholm University, Sweden.

Keys P, Porkka M, Wang-Erlandsson L, Fetzer I, Gleeson T and Gordon L (2019) Invisible water security: Moisture recycling and water resilience. Water Security 8: 100046.

Keys P, Wang-Erlandsson L and Gordon L (2016) Revealing invisible water: moisture recycling as an ecosystem service. PloS one, 11(3).

Keys P, Wang-Erlandsson, L, Gordon L, Galaz V and Ebbesson J (2017) Approaching moisture recycling governance. Global Environmental Change 45: 15-23. 
Kirsch S (2013) Cultural geography I: Materialist turns. Progress in Human Geography 37: 433-441.

Klemeš V (1988) A hydrological perspective. Journal of Hydrology 100(1-3): 3-28.

Linton J (2008) Is the hydrologic cycle sustainable? A historical-geographical critique of a modern concept. Annals of the Association of American Geographers 98: 630-649.

Linton J (2010) What is water? The History of a Modern Abstraction. Vancouver: UBC Press.

Linton J (2014) Modern water and its discontents: a history of hydrosocial renewal. WIREs Water 1:111-120. doi: 10.1002/wat2.1009

McBride, R (2018) Witness statement 16 August 2018 to the Murray-Darling Basin Royal Commission, Adelaide: 1912-1990.

McMahon T, Finlayson B and Peel M (2016) Historical developments of models for estimating evaporation using standard meteorological data. WIREs Water 3: 788-818.

Melo Zurita M and Munro P (2019) Voluminous territorialisation: Historical contestations over the Yucatan Peninsula's subterranean waterscape. Geoforum 102: 38-47.

Murray Darling Basin Authority (2017) Sustainable Diversion Limit Adjustment Mechanism: Draft Determination Report. MDBA, Canberra.

MDBRC, Murray-Darling Basin Royal Commission (2019) Murray-Darling Basin Royal Commission Report. $\quad$ www.mdbrc.sa.gov.au/sites/default/files/murray-darling-basin-royal-commissionreport.pdf?v=1548898371

Newell F (1920) Water Resources: Present and Future Uses. New Haven, CT: Yale University Press. 
NSW Department of Industry (2018) Menindee Lakes Water Saving Project: Summary of the Phase 2 Preliminary Business Case, Concept Design.

Palacios-Velez E (1994) Water use efficiency in irrigation districts. In Efficient Water Use, ed. H. Garduno and F. Arreguin-Cortes. Montevideo: UNESCO/ROSTLAC.

Pittock J, Finlayson C and Howitt J (2013) Beguiling and risky: "environmental works and measures" for wetland conservation under a changing climate. Hydrobiologia 708: 111-31.

Roderick M and Farquhar G (2011) A simple framework for relating variations in runoff to variations in climatic conditions and catchment properties. Water Resources Research 47, W00G07, doi:10.1029/2010WR009826.

Rogers S and Wang M (2020) Producing a Chinese hydrosocial territory: A river of clean water flows north from Danjiangkou. Environment and Planning C: Politics and Space 38 (7-8): 1308-1327. Doi.org/10.1177/2399654420917697

Scott J (1998) Seeing Like a State: How Certain Schemes to Improve the Human Condition Have Failed. New Haven, USA: Yale University Press.

Shah E, Liebrand J, Vos J, Veldwisch G and Boelens R (2018) The UN World Water Development Report 2016, Water and Jobs: A Critical ReviewDevelopment and Change 49(2): 678-691.

SKM (2010) Darling River Water Saving Project Part B. Final Report to the NSW Office of Water and Australian Department of the Environment, Water, Heritage, and the Arts.

Slattery M and Campbell R (2019) A fish kill $Q$ and A: Questions, answers and dead fish in the Menindee Lakes. Canberra: Australia Institute Discussion Paper. 
Slattery M and Johnson B (2021) Floodplain water harvesting in the Northern New South Wales Murray Darling Basin, Unpublished Report, https://irnnsw.files.wordpress.com/2021/02/21022fph-final-report.pdf.

Swyngedouw E (2015) Liquid Power: Contested Hydro-Modernities in Twentieth Century Spain Cambridge, Massachusetts: The MIT Press.

UNESCO 1971. Scientific framework of world water balance. Technical Papers in Hydrology. Paris: UNESCO.

Te Wierik S, Gupta J, Cammeraat E and Artzy-Randrup Y (2019) The need for green and atmospheric water governance. Wiley Interdisciplinary Reviews: Water, e1406.

The Land (2021) Pavey says Menindee water-savings project discussions suspended.

https://www.theland.com.au/story/7172211/menindee-sdl-project-discussions-suspended/

Van der Kooij S, Kuper M, de Fraiture C, Lankford B and Zwarteveen, M (2017) Re-allocating yet-tobe-saved water in irrigation modernization projects: The case of the Bittit irrigation system, Morocco. In Venot J, Kuper M and Zwarteveen M (eds) Drip Irrigation for Agriculture. London: Routledge, pp. 68-84.

Vertessy R et al. (2019) Independent assessment of the 2018-19 fish deaths in the lower Darling, Final Report, https://www.mdba.gov.au/sites/default/files/pubs/Final-Report-Independent-Panelfish-deaths-lower\%20Darling 4.pdf, Accessed 18 July 2020.

Vos J and Hinojosa L (2016) Virtual water trade and the contestation of hydrosocial territories. Water International 41(1): 37-53.

Webb, McKeown \& Association (2007) State of the Darling Interim Hydrology Report. Report for the Murray Darling Basin Commission, March 2007. 
Published in Environment and Planning E: Nature and Space (2021), DOI: 10.1177/25148486211038392

Weng W (2019) Aerial river management for future water in the context of land use change in Amazonia. PhD Thesis, Humboldt Universität zu Berlin - Geographisches Institut, Germany.

Wentworth Group (2017) Review of Water Reform in the Murray-Darling Basin. Canberra. https://wentworthgroup.org/2017/11/review-of-water-reform-in-the-murraydarling-basin/2017/.

World Bank (2017) Making Every Drop Count: High-Level Panel on Water Outcome Document https://sustainabledevelopment.un.org/content/documents/17825HLPW_Outcome.pdf 